\title{
"The impact of discretionary loan loss provision of sharia financing on financial performance"
}

\begin{tabular}{|c|c|c|}
\hline AUTHORS & \multicolumn{2}{|c|}{$\begin{array}{l}\text { Z Zulfikar (D https://orcid.org/0000-0003-3826-7256 } \\
\text { Wahyuni Sri }\end{array}$} \\
\hline ARTICLE INFO & \multicolumn{2}{|c|}{$\begin{array}{l}\text { Z Zulfikar and Wahyuni Sri (2019). The impact of discretionary loan loss } \\
\text { provision of sharia financing on financial performance. Banks and Bank Systems, } \\
14(4), 34-41 \text {. doi:10.21511/bbs.14(4).2019.04 }\end{array}$} \\
\hline DOI & \multicolumn{2}{|c|}{ http://dx.doi.org/10.21511/bbs.14(4).2019.04 } \\
\hline RELEASED ON & \multicolumn{2}{|l|}{ Thursday, 28 November 2019} \\
\hline RECEIVED ON & \multicolumn{2}{|l|}{ Wednesday, 21 August 2019} \\
\hline ACCEPTED ON & \multicolumn{2}{|l|}{ Thursday, 14 November 2019} \\
\hline LICENSE & \multicolumn{2}{|c|}{$\begin{array}{l}\text { This work is licensed under a Creative Commons Attribution } 4.0 \text { International } \\
\text { License }\end{array}$} \\
\hline JOURNAL & \multicolumn{2}{|l|}{ "Banks and Bank Systems" } \\
\hline ISSN PRINT & \multicolumn{2}{|l|}{$1816-7403$} \\
\hline ISSN ONLINE & \multicolumn{2}{|l|}{$1991-7074$} \\
\hline PUBLISHER & \multicolumn{2}{|c|}{ LLC "Consulting Publishing Company "Business Perspectives" } \\
\hline FOUNDER & \multicolumn{2}{|c|}{ LLC "Consulting Publishing Company "Business Perspectives" } \\
\hline $0^{0}$ & 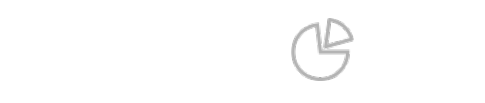 & 三㭉: \\
\hline NUMBER OF REFERENCES & NUMBER OF FIGURES & NUMBER OF TABLES \\
\hline 21 & 1 & 7 \\
\hline
\end{tabular}

(c) The author(s) 2022. This publication is an open access article. 


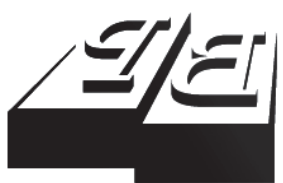

BUSINESS PERSPECTIVES

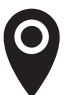

LLC "CPC "Business Perspectives" Hryhorii Skovoroda lane, 10, Sumy, 40022, Ukraine

www.businessperspectives.org

Received on: $21^{\text {st }}$ of August, 201 Accepted on: $14^{\text {th }}$ of November, 2019

(c) Z Zulfikar, Wahyuni Sri, 2019

Z Zulfikar, Graduate, Faculty of Economics, Department of Accounting, Universitas Muhammadiyah Surakarta, Indonesia.

Wahyuni Sri, Graduate, Faculty of Economics, Department of Accounting, Universitas Muhammadiyah Purwokerto, Indonesia.

\title{
THE IMPACT OF DISCRETIONARY LOAN LOSS PROVISION OF SHARIA FINANCING ON FINANCIAL PERFORMANCE
}

\begin{abstract}
This study aims to investigate the role of discretionary loan loss provision of sharia financing on the Islamic commercial banks' financial performance in Indonesia. Partial Least Squares-Structural Equation modeling (PLS-SEM) is used to examine the relationship between loan loss provisions and financial performance in 13 Islamic commercial banks for 4.5 years. The analysis of the outer model shows that the probability of default and loss given default are determinants of loan loss provision, while financial performance is determined by return on assets, non-performing financing, net operating margin, and operating costs on operating income. The results of this study indicate that loan loss provisions have a direct effect on financial performance. Further investigation shows that the return on sharia financing contributes to increasing the impact of loan loss provisions on financial performance (indirect influence). The findings contribute to the literature by showing that discretionary loan loss provision can occur in sharia financing. The study is very important in terms of awareness of management behavior related to financial performance. The study has implications for management policies related to the prerequisites of potential clients.
\end{abstract}

\section{Keywords}

discretionary loan loss provision, sharia financing, probability of default, loss given default, financial performance

\section{JEL Classification $\quad$ G3, H81}

\section{INTRODUCTION}

Sharia is one of the solutions offered by Islamic banks to avoid riba transactions. At the time the contract is made, both Islamic banks (the investor and the customer) do not set specific interest rates as profits received or expenses to be paid. The statement of Financial Accounting Standards (PSAK, 2007, par. 04) defines sharia as a contract of business cooperation between two parties where the first party (the owner of the fund) provides all funds, while the second party (fund manager) acts as a manager. The profits are divided between them according to an agreement, while the financial loss is only borne by the owner of the fund (IAI, 2017). The definition implies that the Bank can act as both the owner of the fund and the fund manager. Sharia funds disbursed by fund owners (the Bank) are recognized as sharia investments when cash payments or transfers of non-cash assets to fund managers occur (PSAK, 2007, par. 12).

However, in practice, when banks act as fund owners, generally applying sharia is more of a financing nature (Suhartini \& Anwar, 2016). As a financing product, sharia has a risk of loss due to loss or negligence of the fund manager (Bank Indonesia, 2013). The risk of loss is anticipated by forming a reserve for impairment of assets. This risk is in accordance with the Decree of the Board of Directors of Bank Indonesia 
No. 31/147/KEP/DIR dated November 12, 1998, which requires the establishment or allowance for earning assets losses. On the other hand, the Statement of Financial Accounting Standards (PSAK) number 50, 2006 (Revised 2014) also regulates the treatment of allowance for possible losses on earning assets in the form of allowance for impairment losses. Banks are required to establish reserves for impairment losses if there is objective evidence of impairment of financial assets as one or more events that have occurred after the recognition of the assets and have an impact on the estimated future cash flows. Allowance for impairment losses is treated as a deduction from sharia financing (Bank Indonesia, 2013).

Loan loss provisions are usually associated with bank management policies in anticipating investment loss risks and improving financial performance. Many studies have succeeded in explaining the relationship between loan loss provisions and financial performance (Ajekwe, Ibiamke, \& Silas, 2017; Ditchkus, Sierra, \& Reed, 2011; Gray \& Clarke, 2004; Leventis \& Dimitropoulos, 2011; Mutiara, 2017). The study is different from previous research. Its uniqueness lies in investigating the specific discretionary focus related to sharia financing and its measurement model.

The main purpose of this study is to analyze the influence of discretionary loan loss provisions for sharia products on the financial performance of Islamic commercial banks; secondly, to investigate the role of sharia income in the context of loan loss provision and financial performance.

\section{LITERATURE REVIEW}

\subsection{Sharia in Islamic banks}

Islamic banks have a variety of products based on sharia financial services. Financial services provided by Islamic banks, as well as conventional banks, cannot be separated from profit motivation. In sharia, there are two forms of contracts that generate benefits for Islamic banks, namely, a sales contract and a contract of cooperation. The sale and purchase contract creates a certain advantage for Islamic banks. The sale and purchase contract of Islamic banks offers products such as murabahah, salam, istisna, and ijarah. While in the contract of cooperation, Islamic banks offer mudaraba and musyaraka. Both of these contracts bring in uncertain profits. The sharia profit obtained by Islamic banks generally comes from contractual agreements (contracts) between banks (such as shahibul mal) and mudarib.

The development of sharia financing is slower than other financing in Islamic banks in Indonesia (Gilang, 2013; Amelia \& Hardini, 2017; Ningsih, 2017). This can be due to the non-performing financial contribution (NPF), which always increases (Gilang, 2013). While Amelia and Hardini (2017) explained that sharia financing can reduce the capital adequacy ratio. One of the causes of the contract failure is the burden upon cap- ital of Islamic banks. However, this problem can be solved by improving the overall determinants of financial performance, such as return on assets (ROA), return on equity (ROA), and financing-to-deposit ratio (FDR) (Ningsih, 2017).

\subsection{Loan loss provision}

Ajekwe et al. (2017) began their research by defining loan loss provisions as a non-cash expense for banks to take into account the possibility of future losses from bad loans. The bank assumes that a certain percentage of the loan will fail or become slow to pay. This method guarantees the solvency and capitalization of the bank if and when a failure occurs (Ajekwe et al., 2017). In terms of accounting for loan loss provisions on Islamic bank products, it can affect the bank's income and capital adequacy. When a bank enters into a sharia cooperation contract, it faces the risk that the customer may fail and return not full assets. The bank assumes that losses that actually occur are recognized as expenses, providing for reserve losses.

Loan loss provisions in Islamic banks refer to the deduction of the bank's net income to provide a failure of a financing contract or non-performing financing. In accounting, the practice of loan loss provisions is reasonable and generally permitted by banking regulations. In the development of further practice, management uses this method to manage compa- 
ny profits. Several studies have empirically proven the use of loan loss provisions as a tool for earnings management in banks (Ajekwe et al., 2017; Ali, Saiti, Hamzah, Razak, \& Ariff, 2015; Taktak, Zouari, \& Boudriga, 2010; Leventis \& Dimitropoulos, 2011).

\subsection{Hypotheses}

Based on previous research, this study has developed the following hypotheses:

H1: Loan loss provisions affect return on sharia financing.

H2: Return on sharia financing affects financial performance.

H3: Loan loss provisions have a direct effect on financial performance.

H4: Loan loss provisions have an indirect effect on financial performance through return on sharia financing.

\section{RESEARCH METHODS}

\subsection{Data}

This study uses cross-sectional data for 4.5 years, from of January 2014 to June 2018. The object of this study is financial reports of 13 Islamic com- mercial banks registered with Bank Indonesia and the Financial Services Authority (OJK). This study observes the financial performance of Islamic Commercial Banks and Sharia Banking Statistics published by each bank and OJK.

\subsection{Variable measurement}

The variables in this study include three latent variables, namely, Loan Loss Provision (dependent), Return on Sharia (intervening) and financial performance (independent). Each of these variables is measured using the following indicators (see Table 1).

Table 1. Latent variables and an indicator (manifest)

\begin{tabular}{|c|c|}
\hline Latent variables & Indicator (manifest) \\
\hline Loan Loss Provision & $\begin{array}{l}\text { POD (Probability of Default) } \\
\text { LGD (Loss Given Default) }\end{array}$ \\
\hline $\begin{array}{l}\text { Return on Sharia } \\
\text { Financing }\end{array}$ & $\begin{array}{l}\text { MII (sharia income to total sharia } \\
\text { investment) } \\
\text { All (administration income to total sharia } \\
\text { investment) }\end{array}$ \\
\hline Financial performance & $\begin{array}{l}\text { ROA (Return on Assets) } \\
\text { NPF (Non-Performing Financing) } \\
\text { OER (Operational Expense to } \\
\text { Operational Revenue) } \\
\text { NOM (Net Operating Margin) }\end{array}$ \\
\hline
\end{tabular}

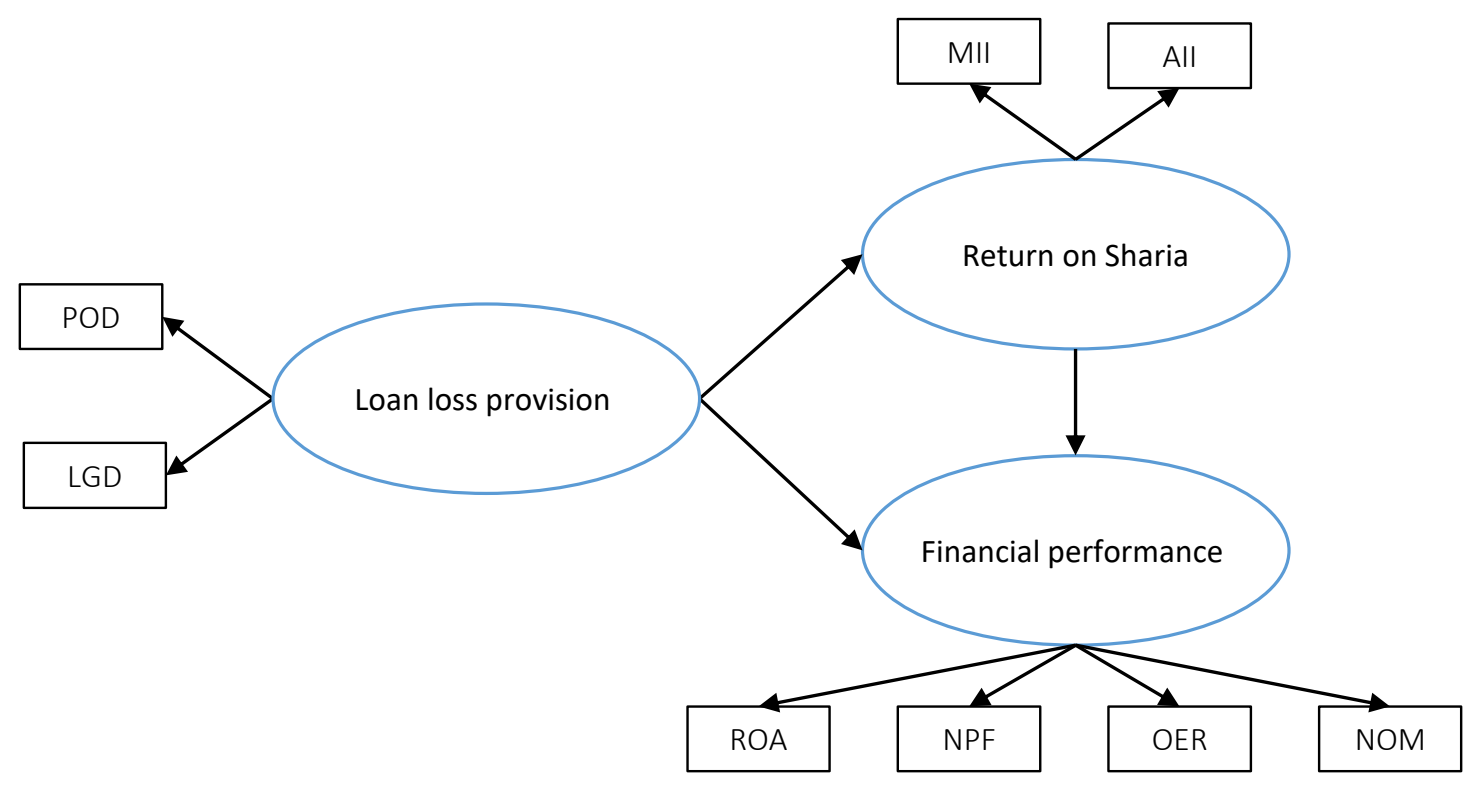

Figure 1. Path diagram analysis 


\section{EMPIRICAL RESULTS AND ANALYSIS}

Partial Least Square-Structural Equation Modeling (PLS-SEM) is used to test the effect of the loan loss provision on the financial performance of Islamic commercial Banks through Return on Sharia. Previously, the path model in the form of a diagram will be used to determine the direction of the relationship between the latent variables (LLP, Return on Sharia, financial performance). The path diagram at the beginning of the analysis is shown in Figure 1.

PLS-SEM analysis produces statistical values grouped into two models, namely, the outer model and inner model.

\subsection{Outer model}

The results of the study of the outer model show that the observed manifest variables can be categorized as determinants of latent variables. The test equipment used includes test validity and test reliability. Validity tests were carried out in two stages, namely, Convergent Validity (Average Variance Extracted) and Discriminant Validity. Table 2 presents the statistical values of Average Variance Extracted (AVE) for latent variables.

Table 2. Average Variance Extracted (AVE) for latent variables

\begin{tabular}{l|c:c:c}
\hline \multicolumn{1}{c}{ Latent variable } & $\begin{array}{c}\text { AVE } \\
\text { statistics }\end{array}$ & $\begin{array}{c}\text { Square root } \\
\text { of AVE }\end{array}$ & Conclusion \\
\hline Loan Loss Provision (LLP) & 0.678 & 0.823 & Valid \\
\hline Return on Sharia (ROS) & 0.764 & 0.874 & Valid \\
\hline Financial performance (FP) & 0.597 & 0.773 & Valid \\
\hline
\end{tabular}

The validity level of the latent variable is measured using the square root value of AVE $\geq 0.5$ (Schumacker \& Lomax, 2010). The square root value of AVE test results are shown in Table 2 for all latent variables more than 0.5 . This concludes that all latent variables are valid criteria.

Subsequent testing is performed on the manifest variable with the latent variable using the Discriminant Validity. The Discriminant Validity procedures are carried out in two stages. The first stage is assessing the value of cross loading and the second stage is the assessing the value of Fornell-
Larcker. Tables 3 and 4 present statistical values for the cross loading and Fornell-Larcker criteria.

Table 3. The value of the cross loading indicator

\begin{tabular}{l|c:c:c}
\hline \multirow{2}{*}{ Indicator } & \multicolumn{3}{|c}{ Latent variable } \\
\cline { 2 - 4 } & LLP & ROS & FP \\
\hline POD & 0.746 & 0.351 & 0.247 \\
\hdashline LGD & 0.578 & -0.134 & 0.216 \\
MII & 0.114 & 0.376 & 0.201 \\
\hline All & -0.211 & 0.489 & -0.189 \\
\hline ROA & 0.254 & 0.387 & 0.468 \\
\hline NPF & 0.289 & 0.278 & 0.534 \\
\hdashline BOPO & 0.198 & 0.305 & 0.387 \\
\hline NOM & -0.467 & 0.308 & 0.486 \\
\hline
\end{tabular}

The value of cross loading shows the connection between indicators with latent variables. The association between latent variables and forming indicators must be higher than the correlation between indicators with other latent variables (Aminah, Suharsono, \& Ahmad, 2016). Cross loading value in Table 3 shows that each indicator value on certain latent variables is greater in the value of other indicators. This points out that the indicators are set to form latent variables. To strengthen these results, the Fornell-Larcker criteria were tested (see Table 4). Table 4 shows the correlation values between the same latent variables, which have greater Fornell-Larcker criterion values than between different latent variables. The test results concluded that latent variables have valid criteria.

Table 4. Fornell-Larcker criteria

\begin{tabular}{l|c:c:c}
\hline Latent variables & LLP & ROS & FP \\
\hline LLP & 0.823 & - & - \\
\hdashline ROS & 0.473 & 0.874 & - \\
\hdashline FP & 0.385 & 0.427 & 0.773 \\
\hline
\end{tabular}

The reliability of each latent variable is tested using the CR value criteria $\geq 0.70$ and $\mathrm{VE} \geq 0.50$ (Schumacker \& Lomax, 2010). Table 5 shows the statistical values for each latent variable. The CR and VE statistical values for each latent variable show numbers greater than 0.70 and 0.50 . These results conclude that all latent variables are reliable so that further testing can be carried out.

Table 5. Reliability of latent variables

\begin{tabular}{l|c:c:c}
\hline Latent variables & $\mathbf{C R} \geq \mathbf{0 . 7 0}$ & VE $\mathbf{2 0 . 5 0}$ & Conclusion \\
\hline LLP & 0.846 & 0.597 & Reliable \\
\hdashline ROS & 0.795 & 0.564 & Reliable \\
\hdashline FP & 0.832 & 0.548 & Reliable \\
\hline
\end{tabular}




\subsection{Inner model}

Testing of the endogenous (Financial Performance) and exogenous (Loan Loss Provision) variable partial relationship is done by inner model analysis. These tests include an accuracy test of the model, a significance test and the relevance of the path coefficients on the structural model. Tables 6 and 7 show the statistical values used to analyze the inner model.

Table 6. The goodness of fit test

\begin{tabular}{l|c:c:c}
\hline $\begin{array}{c}\text { Goodness of fit } \\
\text { measurement }\end{array}$ & Critical value & $\begin{array}{c}\text { Statistical } \\
\text { value }\end{array}$ & Conclusion \\
\hline Chi Square & $\geq 0.05$ & $\begin{array}{c}24.7 \\
(0.057)\end{array}$ & Fit \\
\hline RMSEA & $\leq 0.08$ & 0.0534 & Fit \\
\hline GFI & $\geq 0.09$ & 0.2276 & Fit \\
\hline AGFI & $\geq 0.09$ & 0.1346 & Fit \\
\hdashline TLI & $\geq 0.095$ & 0.1730 & Fit \\
\hline
\end{tabular}

The goodness of fit test aims to determine whether the model is fit so that it can be used to assess relationships between variables (Schumacker \& Lomax, 2010). Some criteria are used to determine the model accuracy, for example, Chi-square, RMSEA, GFI, AGFI, and TLI. Table 6 shows the statistical values of the test results of the criteria for testing the model accuracy (Goodness of Fit) and the size of the critical value. Analysis of the comparison between the test results and the size of the critical value of each test criterion shows that all requirements conclude the model is fit.

Testing of predictive accuracy is indicated by the statistical value of the coefficient of determination $\left(R^{2}\right)$ on the path model that is equal to 0.780 . These results explain that financial performance can be predicted by loan loss provisions, both directly and indirectly, through Return on Sharia of $78 \%$. While the remaining $22 \%$ is likely to be explained by other variables not found in the path model.

The partial analysis to determine the relationship between the variables of Loan Loss Provision, fi- nancial performance, and Return on Sharia uses the significance test and the path coefficients on the structural model. Table 7 shows the statistical values of estimated coefficients and their significance level.

Testing of the first hypothesis is shown by the estimated coefficient value of path ROS $\leftarrow$ LLP with a positive sign of 0.748 and a significance level of 0.0154 (C.R $=5.89$ ) smaller than $\alpha=0.05$. The test results concluded that the higher the loan loss provision, the higher the sharia income, and vice ver$\mathrm{sa}$, the lower the loan loss provision, the lower the sharia income.

The direct effect of loan loss provisions on financial performance is indicated by the magnitude of the estimated coefficient of path FP $\leftarrow$ LLP with a positive sign of 0.249 and a significance level of 0.0251 (C.R $=4.45)$ smaller than $\alpha=0.05$. This result concludes that the second hypothesis is accepted. Thus it can be stated that the higher the loan loss provision, the higher the financial performance, and vice versa, the lower the loan loss provision, the lower the financial performance.

The test results of the third hypothesis conclude that the higher the Return on Sharia, the higher the financial performance, and vice versa, the lower the Return on Sharia, the lower the financial performance. This conclusion is supported statistically as indicated by the magnitude of the estimated coefficient value of the path of $\mathrm{FP}<\mathrm{PM}$ with a positive sign of 0.498 and a significance level of 0.0314 (C.R $=3.83$ ) smaller than $\alpha=0.05$.

The indirect effect of loan loss provisions on financial performance through Return on Sharia is shown by the estimated coefficient value of path $\mathrm{PF} \leftarrow \mathrm{ROM} \leftarrow$ LLP with a positive sign of 0.373 and a significance level of 0.014 (C.R $=2.195)$. This result concludes that the fourth hypothesis which states that loan loss provisions have an indirect effect on financial performance through return on sharia, is accepted.

Table 7. Hypothesis test

\begin{tabular}{|c|c|c|c|c|c|c|c|}
\hline Hypothesis & Path & Estimate & S.E & C.R & $\rho$-value & $R^{2}$ & Conclusion \\
\hline $\mathrm{H} 1$ & $\mathrm{ROM} \leftarrow \mathrm{LLP}$ & 0.748 & 0.197 & 5.89 & 0.0154 & \multirow{3}{*}{0.780} & Accepted H1 \\
\hline $\mathrm{H} 2$ & $\mathrm{FP} \leftarrow \mathrm{LLP}$ & 0.249 & 0.176 & 4.45 & 0.0251 & & Accepted H2 \\
\hline $\mathrm{H} 3$ & $\mathrm{FP} \leftarrow \mathrm{ROS}$ & 0.498 & 0.185 & 3.83 & 0.0314 & & Accepted H3 \\
\hline $\mathrm{H} 4$ & $\mathrm{FP} \leftarrow \mathrm{ROS} \leftarrow \mathrm{LLP}$ & 0.373 & - & 2.195 & 0.0140 & - & Accepted H4 \\
\hline
\end{tabular}




\section{DISCUSSION}

The results of the analysis of the outer model show that the probability of default variable and loss given default as manifest variables correlate to the variable of loan loss provisions. Thus it can be concluded that the probability of default and loss given default variables are determinants of loan loss provision variables. This result is in line with research conducted by Misankova, Spuch, and Frajtova (2015) and Ali et al. (2015). Misankova, Spuch, and Frajtova (2015) explain that loan loss provisions are financing management risks that can be determined by the likelihood of a mudarib failing to pay at the probability of default and the number of assets that failed to be acquired (loss given default). Ali et al. (2015) measure the determinants of loan loss provisions caused by two things, namely, the probability of failure measured by a probability of default and the value of assets that fail to collect the total bill (loss given default).

Friyanto (2013) analyzed the risk of sharia financing on a Sharia bank as a case study. The result of the analysis recommends the need for billing schedules and minimizes the value of failed assets (loss given default) by making certain covenants for customer. This shows that monitoring of the probability of default and the failed asset value (loss given default) is an essential element in determining loan loss provisions (Friyanto, 2013).

The outer model also examines the determinants of the Sharia commercial banks' financial performance, which includes four manifest variables, namely: return on assets (ROA), non-performing financing (NPF), net operating margin (NOM), and the ratio of operating expenses to operating revenue (OER). This study concludes that the four variables have a strong correlation with the variable financial performance as the latent variable. Testing of these financial ratios is in line with research conducted by Zulfikar and Sasongko (2016). In different ways, these financial ratios explain financial performance affecting the competitiveness of Islamic banking services in Indonesia (Zulfikar \& Sasongko, 2016).

The results of the analysis of the inner model concluded that the proposed hypotheses (H1 s.d. H4) in this study were significantly supported by statistical values both partially and throughout the model. Each exogenous variable (loan loss provision and return on sharia) explains the positive relationship to endogenous variables (financial performance).

Testing of the first hypothesis proves that loan loss provisions have a significant positive effect on return on sharia. Proper management of loan loss provisions will increase return on sharia. This study agrees with Liu (2017) that loan loss provisions are part of the anticipatory steps taken by banks to reduce financing risk. Knowledge of probability of default and loss given default as a determinant of discretionary loan loss provision is an early warning for bank managers to reduce the failure to obtain income derived from sharia financing. Determination of probability of default and loss given default is an effective way for bank management to increase financing income (Misankova et al., 2015).

This study proves that loan loss provisions affect financial performance. The statement is supported by the result of path coefficient test with positive and significant directions. The discretionary loan loss provision has a positive effect on financial performance as measured by return on assets (ROA), non-performing financing (NPF), net operating margin (NOM), and the ratio of operating expenses to operating revenue (OER). The discretionary loan loss provision effectively demonstrates the ability of banks to increase sharia investment returns (Meutia, 2017). Sharia investment returns will have a positive direct impact on increasing ROA, NOM, OER and decreasing NPF (Aminah et al., 2016).

This study also proves that return on sharia is a mediating variable of the indirect effect of loan loss provisions on financial performance. Even the influence of loan loss provisions on financial performance is stronger if it is through return on sharia compared to its direct influence. This finding strengthens previous research that income derived from investing in bank financing is the main focus of management in managing loan loss provisions (Ajekwe et al., 2017; Ditchkus et al., 2011; Gray \& Clarke, 2004; Leventis \& Dimitropoulos, 2011). 


\section{CONCLUSION}

The study of loan loss provisions in sharia financing concludes several discretionary characteristics of loan loss provisions in Islamic commercial banks in Indonesia.

Firstly, the discretionary loan loss provision of sharia financing has a direct effect on return on sharia and the financial performance of Islamic commercial banks. The discretionary loan loss provision refers to two default models, namely, the probability of default and loss given default. Both models have implications for management policies related to the prerequisites of potential customer candidates that must be studied in more detail to reduce the risk of sharia financing. Both models also have implications for improving the monitoring of billing sharing and return on asset collection schedules by customer.

Secondly, the discretionary loan loss provision of sharia financing has an indirect impact on financial performance through return on sharia. The results of this study emphasize that the indirect influence is stronger than the direct one. The combination of loan loss provision policies and income on sharia financing can facilitate Islamic bank executives in predicting income volatility, which in turn affects corporate profits. The next effect is the ability of managers to pursue income smoothing policies through loan loss provisions.

\section{REFERENCES}

1. Ajekwe, C. C., Ibiamke, A., \& Silas, M. F. (2017). Loan Loss Provisions, Earnings Smoothing and Capital Management Under IFRS: The Case of Deposit Money Banks in Nigeria. American Journal of Management Science and Engineering, 2(4), 58-64. https://doi.org/10.11648/j. ajmse.20170204.12

2. Ali, F., Saiti, B., Hamzah, S., Razak, A., \& Ariff, M. (2015). The impact of efficiency on discretionary loans/finance loss provision: A comparative study of Islamic and conventional banks. Borsa Istanbul Review, 15(4), 272-282. https://doi. org/10.1016/j.bir.2015.06.002

3. Amelia, E., \& Hardini, E. F. (2017). Determinant of Shariah Financing: A Study at Indonesian Islamic Rural Banking. Etikonomi, 16(1), 43-52. https://doi.org/10.15408/ etk.v16i1.4638

4. Aminah, F. N., Suharsono, A., \& Ahmad, S. (2016). Pengaruh Rasio Keuangan Terhadap Nilai Perusahaan pada Sektor Perbankan yang Tercatat di Bursa Efek Indonesia Menggunakan Metode Structural Equation Modelling-Partial Least Square. Jurnal Sains Dan Seni ITS, 5(2), 402-407. Retrieved from https://media.neliti.com/media/ publications/133104-ID-pengaruh-rasio-keuangan-terhadapnilai-p.pdf

5. Bank Indonesia. (2013). Pedoman Akuntansi Perbankan Syariah Indonesia (PAPSI). Retrieved from https://www.ojk.go.id/id/ kanal/perbankan/Documents/ Pages/Pedoman-Akuntansi-Perbankan-Indonesia-\%28PAPI\%29/ PEDOMAN\%20AKUNTANSI\%20PERBANKAN\%20 SYARIAH $\% 20 I N D O N E S I A \% 20$ \%28PAPSI\%29.pdf

6. Taktak, N. B., Zouari, S. B. S., \& Boudriga, A. K. (2010). Do Islamic banks use loan loss provisions to smooth their results? Journal of Islamic Accounting and Business Research, 1(2), 114-127. https://doi. org/10.1108/17590811011086714

7. Ditchkus, L. V., Sierra, G. E., \& Reed, B. J. (2011). The Role of Managerial Prudence in Bank Loan Loss Provisioning, 23(4), 447464. Retrieved from https://www. jstor.org/stable/23209109

8. Friyanto. (2013). Pembiayaan Shariah, Risiko dan Penanganannya (Studi Kasus pada Bank BTN Kantor Cabang Syariah Malang). Jurnal Manajemen Dan Kewirausahaan, 15(2), 113-
122. https://doi.org/10.9744/

jmk.15.2.113-122

9. Gilang, N. G. (2013). Faktor yang Mempengaruhi Pembiayaan Shariah pada Bank Umum Syariah di Indonesia. Accounting Analysis Journal, 2(1), 96-103. https://doi. org/ISSN 2252-6765

10. Gray, R. P., \& Clarke, F. L. (2004). A Methodology for Calculating the Allowance for Loan Losses in Commercial Banks. ABACUS, 40(3), 321-341. https://doi.org/10.1111/j.14676281.2004.00161.x

11. PSAK. (2007). Pernyataan Standar Akuntansi Keuangan (PSAK) No. 105: Akuntansi Mudharabah. Jakarta: Ikatan Akuntan Indonesia. Retrieved from https://jassmh. files.wordpress.com/2017/01/105mudharabah.pdf

12. Kurniawanti, A., \& Zulfikar, Z. (2014). Analisis Faktor-Faktor yang Mempengaruhi Volume Pembiayaan Berbasis Bagi Hasil pada Bank Umum Syariah di Indonesia. Seminar Nasional Dan Call for Paper Program Studi Akuntansi FEB UMS 25 Juni 2014, 145-164. Retrieved from https://core.ac.uk/download/ pdf/148602985.pdf 
13. Leventis, S., \& Dimitropoulos, P. E. (2011). Loan Loss Provisions . Earnings Management and Capital Management under IFRS: The Case of EU Commercial Banks. Journal of Finance Service Research, 40, 103-122. https://doi. org/10.1007/s10693-010-0096-1

14. Liu, L. Y. (2017). Estimating Loss Given Default from CDS under Weak Identification Estimating Loss Given Default from CDS under Weak Identification (No. RPA 17-01). Boston US. Retrieved from http://www.bostonfed.org/ bankinfo/qau/wp/\%0A

15. Meutia, I. (2017). Empirical Research on Rate of Return. Interest Rate and Shariah Deposit. International Journal of Accounting Research, 05(01), 1-5. Retrieved from https://www.semanticscholar. org/paper/Empirical-Researchon-Rate-of-Return\%2C-InterestRate-Meutia/63ce6a02aa121e6460 7b3522c3e15adfdd7f6208
16. Misankova, M., Spuch, E., \& Frajtova, K. (2015). Determination of Default Probability by Loss Given Default. Procedia Economics and Finance, 26(15), 411-417. https://doi.org/10.1016/S22125671(15)00815-1

17. Mutiara, M. M. M. (2017). Cadangan Kerugian Penurunan Nilai Pada Pembiayaan Shariah. Universitas Islam Negeri Maulana Malik Ibrahim Malang. Retrieved from http://etheses.uin-malang. ac.id/10281/1/14801006.pdf

18. Ningsih, D. F. (2017). Analisis Faktor yang Mempengaruhi Pembiayaan Shariah pada Bank Umum Syariah di Indonesia Periode 2013-2016. Jurnal Ilmiah Riset Akuntansi, 6(4), 147-161. Retrieved from http://riset.unisma. ac.id/index.php/jra/article/ view/352/395

19. Schumacker, R. E., \& Lomax, R. G. (2015). A Beginner's Guide to Structural Equation Modeling (4th ed.). Routledge. Retrieved from https://www.amazon.com/Beginners-Guide-Structural-EquationModeling/dp/1138811939

20. Suhartini, M., \& Anwar, S. (2016). Penerapan Cadangan Kerugian Penurunan Nilai. Pendapatan Murabahah dan Kinerja Keuangan pada Bank Umum Syariah Tahun 2014. Jurnal Liquidity, 5(2), 119-126. Retrieved from https:// www.semanticscholar.org/paper/ Penerapan-Cadangan-KerugianPenurunan-Nilai\%2C-Dan-Suhartini-Anwar/2ae2587cf2a01e6c2783 88ba1f66853d14947bfe

21. Zulfikar, Z., \& Sasongko, N. (2016). The Model of Policy the Banking Services to Enhance Competitiveness Islamic Banking in Indonesian. South East Asia Journal of Contemporary Business, Economics and Law, 11(1), 1-8. Retrieved from https:// seajbel.com/wp-content/uploads/2017/01/ACC-106-1.pdf 